\title{
Demographic Parameters of Yellowfin Croaker, Umbrina roncador (Perciformes: Sciaenidae), from the Southern California Bight ${ }^{1}$
}

\author{
Daniel F. Pondella II, ${ }^{2,3}$ Fohn T. Froeschke, ${ }^{4}$ Lynne S. Wetmore, ${ }^{3}$ Eric Miller, ${ }^{5}$ Charles F. Valle, ${ }^{6}$ \\ and Lea Medeiros ${ }^{7}$
}

\begin{abstract}
The yellowfin croaker, Umbrina roncador Jordan \& Gilbert, 1882, is a common nearshore and surf-zone species in the southern California bight. Age was determined for individuals $(n=1,209)$ using annual increments in otoliths, and size at age was modeled using the von Bertalanffy growth curve ( $L_{\infty}=$ $307.754 \mathrm{~mm}, k=0.278 \mathrm{yr}^{-1}, t_{0}=-0.995 \mathrm{yr}$; maximum age $\left.=15 \mathrm{yr}\right)$. Females $\left(L_{\infty}=313.173 \mathrm{~mm}, k=0.307 \mathrm{yr}^{-1}, t_{0}=-0.771 \mathrm{yr}\right)$ grew significantly faster and larger than males $\left(L_{\infty}=298.886, k=0.269 \mathrm{yr}^{-1}, t_{0}=-1.072 \mathrm{yr}\right)$. Age and growth modeling based upon otolith length (OL) and width (OW) measurements were assessed and were consistent with body measurements. Males and females were found in all size classes and in an overall 51:49 ratio that was not significantly different from a $50 \%$ sex ratio, suggesting that these fish are gonochores. Fish were reproductive during summer months, with gonadosomatic indices (females, 5.65\%; males, 5.51\%) consistent with group-spawning fishes. Data from two separate monitoring programs indicated that yellowfin croaker catch-per-unit-effort (CPUE) fluctuated appreciably from 1992 to 2006 on both spatial and temporal scales. CPUE also declined significantly in the latter years of these programs. Based on samples collected between 2003 and 2004, an estimate of overall annual total mortality was $A=0.4492$, and instantaneous coefficient of total mortality was estimated at $Z=0.5964$. Recruitment year classes were back calculated using annual survivorship. Year class strength was variable and declined significantly by the end of this study. Considering the high temporal and spatial variation in estimates of abundance and recruitment, coupled with the likelihood that these fish employ a probable group-spawning reproductive behavior, we recommend a cautious approach for the future management of this species.
\end{abstract}

\begin{abstract}
${ }^{1}$ Funding for this study was provided by the California Department of Fish and Game's Ocean Resource Enhancement Hatchery Program, Chevron Products Company, and the California Energy Commission's Water Intake Structure Environmental Research (WISER) program. This report was prepared as a result of work sponsored by the California Energy Commission (Energy Commission). It does not necessarily represent the views of the Energy Commission, its employees, or the State of California. The Energy Commission, the State of California, its employees, contractors, and subcontractors make no warranty, express or implied, and assume no legal liability for the information in this report; nor
\end{abstract}

Pacific Science (2008), vol. 62, no. 4:555-568

(C) 2008 by University of Hawai'i Press

All rights reserved does any party represent that the use of this information will not infringe upon privately owned rights. This report has not been approved or disapproved by the Energy Commission nor has the Energy Commission passed upon the accuracy or adequacy of the information in this report. Manuscript accepted 31 August 2007.

2 Corresponding author (e-mail: Pondella@oxy.edu).

${ }^{3}$ Department of Biology and Vantuna Research Group, Moore Laboratory of Zoology, Occidental College, 1600 Campus Road, Los Angeles, California 90041.

${ }^{4}$ Texas A\&M University-Corpus Christi, 6300 Ocean Drive, Corpus Christi, Texas 78412.

${ }^{5}$ MBC Applied Environmental Sciences, 3000 Red Hill Avenue, Costa Mesa, California 92626.

${ }^{6}$ California Department of Fish and Game, 4665 Lampson Avenue, Suite C, Los Alamitos, California 90720.

${ }^{7}$ Rosenstiel School, 4600 Rickenbacker Causeway, Miami, Florida 33149-1098. 
The croaker family (Sciaenidae) dominates nearshore soft-bottom, estuarine and freshwater habitats throughout temperate and tropical waters (Nelson 2006). Due to their abundance and this accessibility they support important commercial, recreational, and artisanal fisheries wherever they are found. Southern California currently has commercial fisheries for white seabass (Atractoscion nobilis) and white croaker (Genyonemus lineatus) (Vojkovich and Reed 1983, Love et al. 1984). White croaker and queenfish (Seriphus politus) are commonly used for bait (Eschmeyer and Herald 1983), and spotfin croaker (Roncador stearnsii), shortfin corvina (Cynoscion parvipinnis), and California corbina (Menticirrbus undulatus) are valued sportfish. Sciaenids are typically schooling species, and, where observed, they form spawning aggregations in the nearshore environment. This behavior can lead to overexploitation (Sala et al. 2001), and four croakers are listed as threatened or endangered species in North America (Musick et al. 2000).

The most recognizable feature of the southern California coastline is long stretches of sandy beaches, which attract millions of tourists and thousands of anglers annually. In spite of their considerable potential for anthropogenic impacts, the fishes of this habitat are the least-studied assemblage in the southern California bight. The last synoptic survey was completed in the mid-1950s (Carlisle et al. 1960).

An abundant member of this community is the yellowfin croaker, Umbrina roncador Jordan \& Gilbert, 1882 (Allen and Pondella 2006). Commercial take of this species has been banned since 1909, and it has remained a popular sportfish (Skogsberg 1939, O’Brien and Oliphant 2001). Native Americans fished for yellowfin croaker throughout most of the Holocene, and during that period it was not caught above Point Conception, the northern edge of its range today (Miller and Lea 1972, Gobalet 2000). Thus, it is a component of the warm temperate San Diegan Province, distributed as far south as Magdalena Bay, and has also been observed in the Gulf of California (Allen and Robertson 1994, De La CruzAgüero et al. 1994, Love et al. 2005).
A recent assessment of fishes just beyond the surf zone (5-14 $\mathrm{m}$ deep) found that yellowfin croaker was the most abundant species on the southern California mainland and third most abundant at Santa Catalina Island (Pondella and Allen 2000). Yellowfin croakers have a chin barbel and an inferior jaw typical of soft benthos foragers. Thus, it is not unexpected that previous investigators described this species as preferring shallow sandy substrates, embayments (Skogsberg 1939, Horn and Allen 1985), and especially the surf zone, and it has also been noted around rocks (Feder et al. 1974). Despite its relatively high density, widespread presence in the easily accessible nearshore environment, and importance in recreational fisheries, there is a paucity of life history information about this species. Thus, studies of their life history and demographic characteristics constitute a critical endeavor for conservation and management of this species. In addition, such studies can provide valuable insights into the function and health of the little-studied surfzone ecosystem of the southern California bight.

\section{MATERIALS AND METHODS}

Yellowfin croaker were collected primarily using experimental gill nets as part of the monitoring for California Department of Fish and Game's Ocean Resources Enhancement Hatchery Program (OREHP). From 1995 to 2006, 7,757 yellowfin croaker were captured at 12 stations in the southern California bight (Figure 1) (Pondella and Allen 2000). In this program, six replicate monofilament gill nets, each $45.7 \mathrm{~m}$ in total length and $2.4 \mathrm{~m}$ in depth, and consisting of six panels $7.62 \mathrm{~m}$ long (two each of 25.4, 38.2, and $50.8 \mathrm{~mm}$ square mesh), were deployed on the bottom in the late afternoon and retrieved the following morning. Sampling was conducted annually in April, June, August, and October from April 1995 through October 2006. In 20052006 sampling was conducted in June and October. Malibu, Newport, Palos Verdes, Seal Beach, and Ventura were sampled in all years. Sampling at Oceanside and Point Loma ended in June 1996. At the remaining 


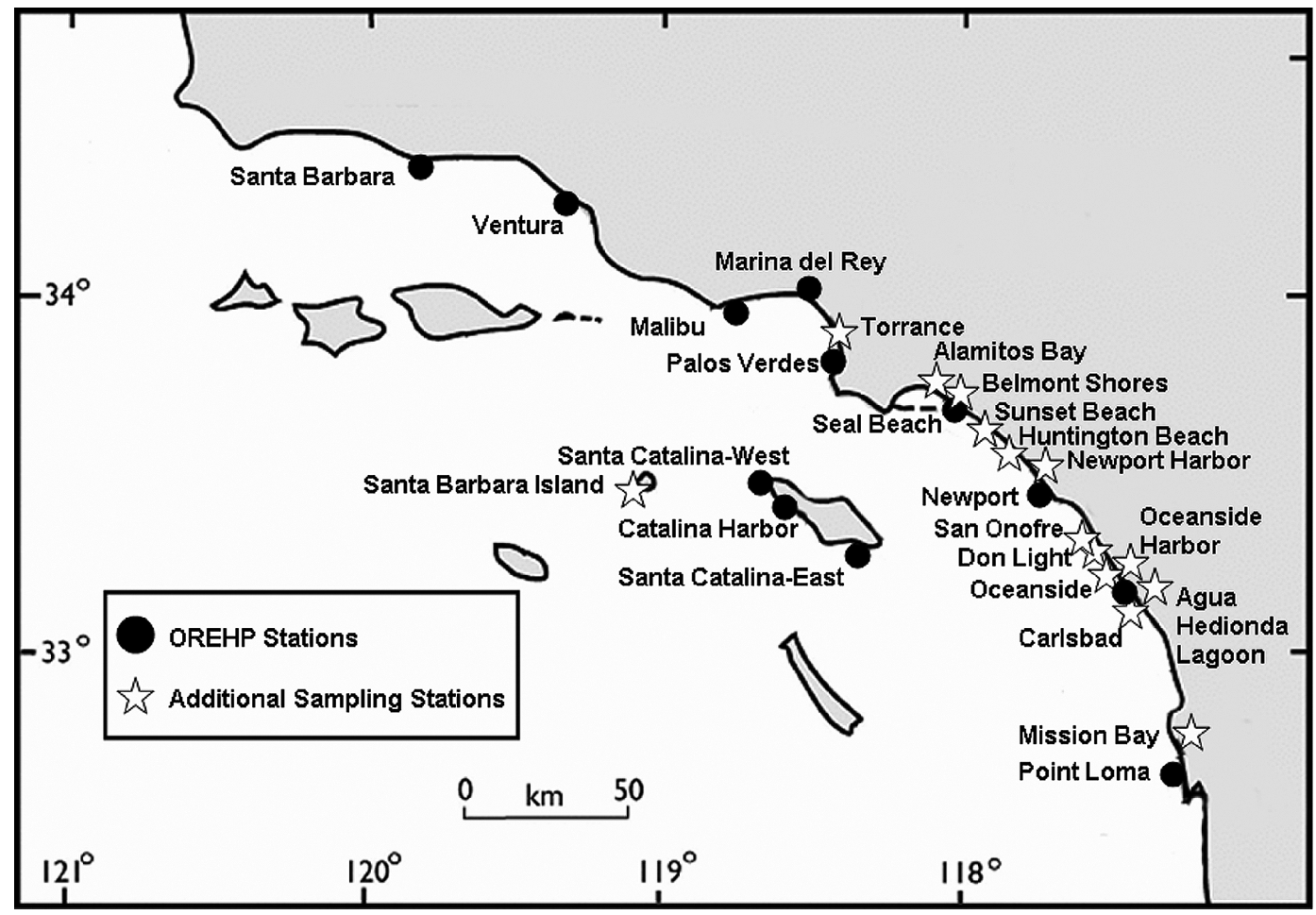

FIgURE 1. Locations of the OREHP monitoring stations and the additional sampling stations in the southern California bight.

stations sampling began in August 1996 with the exception of Marina del Rey, where sampling began in October 1996. East End, Santa Catalina Island, was not sampled in 20052006. Nets were set in 5-14 $\mathrm{m}$ depth on sandy bottom usually just outside the surf zone and either close to kelp beds or on the fringe of rocky reefs. The exceptions to this protocol were Marina del Rey and Seal Beach, which do not have rocky reefs or kelp beds. Marina del Rey is part of the Ballona Wetland system but has been converted to a small-craft marina. As such, nets were set out of the boating lanes in two locations. Three were set parallel to the riprap between the U.S. Coast Guard and UCLA docks, and three were set in Mother's Beach. At Seal Beach the nets were set along the eastern stretch outside the surf zone on the sand near the west jetty, which borders the entrance to the Anaheim Bay and Huntington
Harbor part of the Bolsa Chica wetlands. Nets were set approximately $1 \mathrm{hr}$ before sunset and retrieved $1 \mathrm{hr}$ after sunrise.

Data from the collections were used to calculate catch-per-unit-effort (CPUE) by station and year by calculating the total catch per station (all nets combined). Summarizing the data in this fashion, although reducing power, resulted in removing zero catches from the matrix, alleviated concerns of autocorrelation among replicates (Studenmund 2001), and allowed parametric statistical methods to be employed. A one-way analysis of variance (ANOVA) was used to test for differences in mean CPUE among stations sampled from 1996 to 2004. Before the ANOVA, values of CPUE by station and date were transformed using $\log _{10}(x+1)$ to satisfy the assumption of normality. Normality was tested using Shapiro-Wilks $w$ statistic (Legendre and Legendre 1998). The CPUE 
by sampling period for all stations was then calculated and correlated (Pearson's $r$ ) with mean monthly sea-surface temperature (SST) as recorded at the Newport Pier (www.sccoos .org).

A second time-series data set was analyzed as a measure of relative temporal abundance of yellowfin croaker. Total number of yellowfin croaker entrapped in the coolingwater systems at San Onofre Nuclear Generating Station (SONGS) Units 2 and 3 was evaluated for the period 1992 to 2002. The intake structure is a $3.7 \mathrm{~m}$ Mean Low Low Water (MLLW) riser that is $960 \mathrm{~m}$ offshore at a depth of $9.1 \mathrm{~m}$ (Love et al. 1989). Mean number of entrapped croaker per survey was analyzed across all months for the time period, as well as on an annual basis. A total of 313 cooling-water surveys was conducted at the two units from 1992 to 2002. Mean annual and monthly SST, as recorded at the Scripps Pier (Scripps Institution of Oceanography, La Jolla, California), was correlated (Pearson's $r$ ) with the mean annual, monthly, number per survey.

During the 2003-2004 OREHP sampling seasons, sagittal otoliths were collected from 866 yellowfin croaker. An additional 21 individuals were collected in beach seines, and three individuals were collected on hook and line. The following measurements were made in the field: head length (HL), standard length (SL), fork length (FL), total length (TL), total wet body weight (TW), and gonad weight $(\mathrm{GW})$. Hanging spring scales (Pesola) were used to measure TW to the nearest gram and GW to the nearest $0.5 \mathrm{~g}$. All length conversions followed a linear model, and weight-length relationships were determined using the power function: $W=$ $a L^{b}$, where $W=$ weight (g), and $a$ and $b=$ species-specific constants that were modeled in Microsoft Excel. A gonadosomatic index (GSI) in percentage was determined to estimate seasonal patterns of reproduction, where $\mathrm{GSI}=(\mathrm{GW} /((\mathrm{TW})-(\mathrm{GW})) * 100$ (Barbieri et al. 1994). The proportion of males to females was tested against an extrinsic hypothesis of a $50 \%$ sex ratio using the chi-square distribution (Sokal and Rohlf 2000).
An additional 319 samples from size classes that were underrepresented in the ORHEP sampling were provided by the California Department of Fish and Game. Otoliths from those samples, collected in 1994-1997 during seine and trawl studies (collection sites shown as "Additional Sampling Stations" in Figure 1), were combined with ORHEP otolith samples and used to complete the overall growth curve. In the laboratory, otolith length $(\mathrm{OL})$ and width $(\mathrm{OW})$ were measured $( \pm 0.01 \mathrm{~mm})$ with a digital caliper (Mitutoyo), and the otoliths were weighed $(\mathrm{OWt}$, $\pm 0.0001 \mathrm{~g}$ ) with an analytical balance (Sartorius). All length conversions followed a linear model, and weight-length relationships were determined using the power function: $W=$ $a L^{b}$, where $W=$ weight (g), and $a$ and $b=$ species-specific constants that provided the best fit to this model in a Microsoft Excel fitting routine.

Otoliths were sectioned and used to determine age following the procedures of Craig et al. (1999) using reflected light. Annuli on otoliths appeared as opaque and translucent bands, consistent with results from other sciaenids and fishes from the area. Whether the otolith edge was opaque or translucent was recorded, because this indicates the relative rate of growth of the fish (LowerreBarbieri et al. 1994). We successfully determined age for all 1,209 individuals. Length (SL), OL, and OW at age were modeled with the nonlinear regression procedure in SYSTAT (SPSS Inc., version 11) using the von Bertalanffy growth equation: $L_{t}=$ $L_{\infty}\left(1-e-{ }^{k(t-t o)}\right)$, where $L_{t}=$ standard length at age $t, L_{\infty}=$ theoretical maximum standard length, $k=$ constant expressing the rate of approach to $L_{\infty}$, and $t_{0}=$ theoretical age at which $L_{t}=0$. Fifteen fish from the gill nets were partially eaten, and their SL was estimated from the HL (Table 1). Growth curves were modeled for all individuals pooled and separately for males pooled and females pooled; immature fish were included in all models. The three parameters, $L_{\infty}, k$, and $t_{0}$, for each sex were tested for differences versus the $F$-distribution using the residual sum of squares and following a nonlinear method referred to as "extra sum of squares" or "condi- 


\section{TABLE 1}

Conversion Equations Relating Head Length (HL), Standard Length (SL), Fork Length (FL), Total Length (TL), Otolith Length (OL), and Otolith Width (OW), All in Millimeters, and Quality of Linear Fit $\left(R^{2}\right)$

\begin{tabular}{lc}
\hline \hline Conversion Equation & $R^{2}$ \\
\hline $\mathrm{FL}=1.1413 \mathrm{SL}+7.7108$ & 0.9937 \\
$\mathrm{TL}=1.2072 \mathrm{SL}+2.9756$ & 0.9959 \\
$\mathrm{TL}=1.0423 \mathrm{FL}-0.2072$ & 0.9952 \\
$\mathrm{SL}=3.3569 \mathrm{HL}+21.077$ & 0.9430 \\
$\mathrm{FL}=3.823 \mathrm{HL}+31.871$ & 0.9513 \\
$\mathrm{TL}=3.9895 \mathrm{HL}+32.716$ & 0.9525 \\
$\mathrm{SL}=28.753 \mathrm{OL}-36.877$ & 0.9246 \\
$\mathrm{SL}=56.176 \mathrm{OW}-73.233$ & 0.8096 \\
\hline
\end{tabular}

Note: HL, SL, FL, and TL were measured to the nearest millimeter with a measuring board in the field.

tional error principle" in SYSTAT (Ratowski 1983, Craig et al. 1999).

Using the ages of the fish caught during the 2003-2004 OREHP sampling season, the instantaneous coefficient of total mortality $(Z)$ and overall annual mortality $(A)$ were estimated using the following equations from Ricker (1975): $N_{1} / N_{0}=e^{-Z}$ and $Z=$ $-\ln (1-A)$. In our calculations $N_{0}$ was the number of individuals in an age class cap- tured in 2003, and $N_{1}$ was the number of individuals in the subsequent age class caught in 2004. Mortality rates were calculated for each age class and over all year classes. Birth years were then calculated by subtracting age from the catch date and then adjusted for the rate of survival $(1-A)$ to examine annual recruitment class strength. Time-series trends were described using a linear regression model. All statistical routines were run in Statistica (version 7.0) unless otherwise noted.

\section{RESULTS}

From 1996 to 2004 in the OREHP monitoring program mean CPUE ranged from a high of 65.3 ( \pm 13.3 standard error [SE]) individuals per station at Seal Beach to a low of 1.4 $( \pm 0.4 \mathrm{SE})$ individuals per station at Ventura (Figure 2). Mean CPUE was consistent at all the Catalina stations, ranging from $23.2( \pm 3.3$ $\mathrm{SE})$ to $24.4( \pm 4.4 \mathrm{SE})$ individuals per station at Catalina Harbor and Santa Catalina-West End, respectively. Mean CPUE at Ventura, Santa Barbara, and Malibu was significantly lower than at the remaining stations with two exceptions (ANOVA, $F=19.9 ; \mathrm{df}=$ 9, 329; $P<.001$. Tukey's post hoc test, $P<$ $.001)$. CPUE at Malibu was not significantly

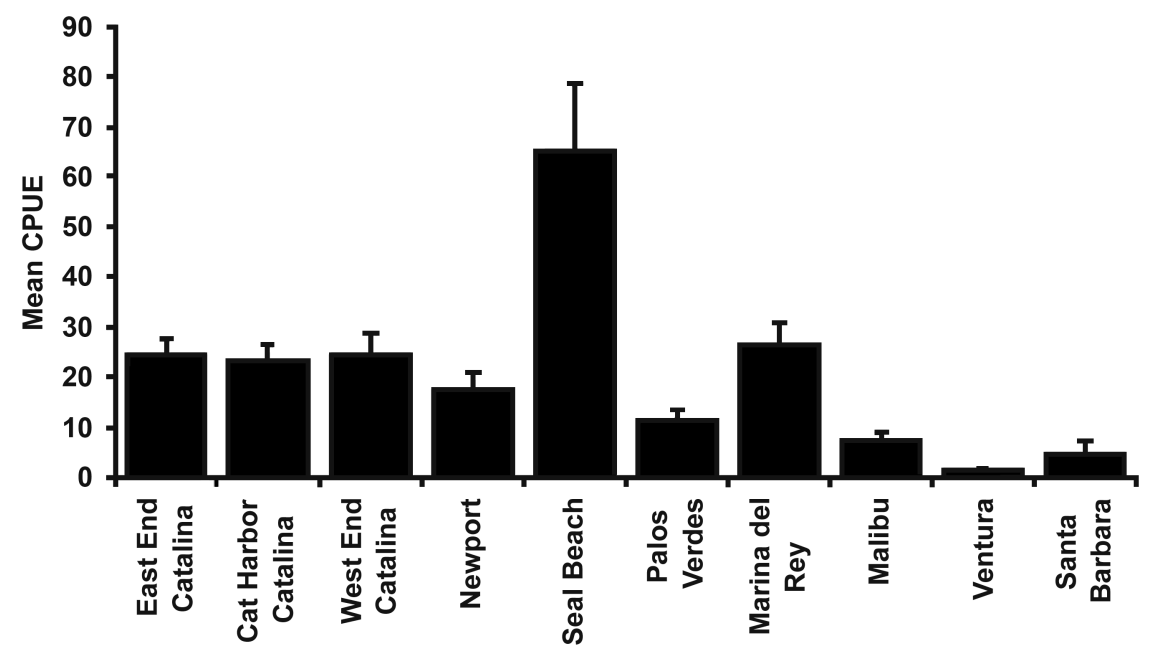

Figure 2. Mean CPUE, number of fish per station ( $\pm 1 \mathrm{SE})$, at 10 stations in the southern California bight from 1996 to 2004 was significantly different (ANOVA, $F=19.9$; $\mathrm{df}=9,329 ; P<.001$. Tukey's post hoc test, $P<.001$ ). 


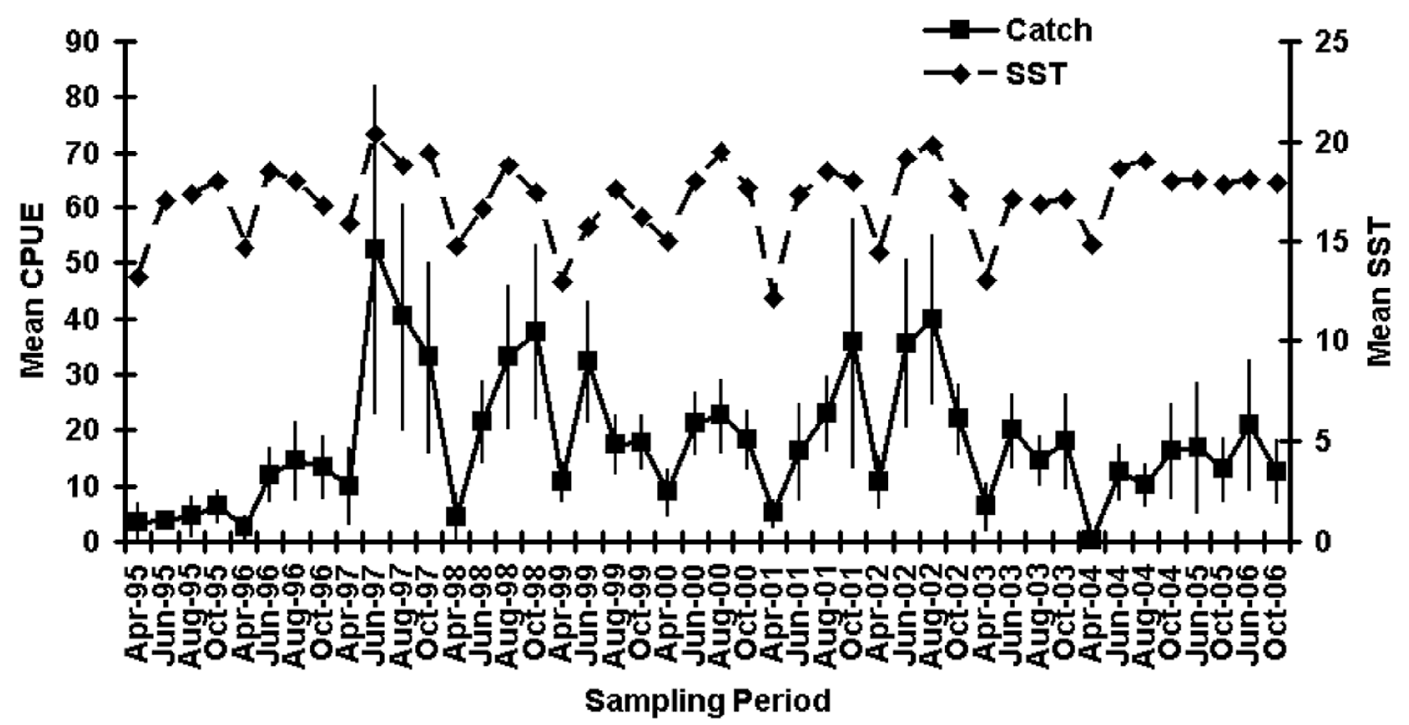

Figure 3. Mean CPUE, number of fish per station $( \pm 1 \mathrm{SE})$, per sample period for all stations pooled and mean monthly SST $\left({ }^{\circ} \mathrm{C}\right)$ measured at the Newport Pier from 1995 to 2006 were significantly correlated $(r=0.63$, $P<0.001)$.

different from that at Newport and Palos Verdes.

For all stations pooled over the full study period, CPUE began at a mean of $3.4( \pm 3.4$ SE) individuals per station in April 1995, increased to $20.4( \pm 29.6 \mathrm{SE})$ in June 1997 , and then showed a significant roughly linear decline $(r=0.45, P=.007)$ over most of the period since. The lowest catch $(0.3$ individuals per station $\pm 0.3 \mathrm{SE}$ ) was in April 2004 (Figure 3). Variation in CPUE over the study period was correlated with mean SST $(r=$ $0.63, P<.001)$ with catch generally greater in the summer or fall. Yellowfin croaker were primarily caught at SONGS during the summer and fall, a seasonal pattern that was significantly correlated with monthly mean SST (Figure $4 a, r=0.809, P=.001$ ). The number of fish entrapped annually at SONGS varied between a low of $25.9( \pm 8.6 \mathrm{SE})$ fish per survey in 1993 and a high of 1,045.4 $( \pm 397.7 \mathrm{SE})$ in 1999 (Figure $4 b)$ and was negatively correlated with SST $(r=-0.751$, $P=.008)$.

Fishes caught in gill nets are routinely fed upon by scavengers and predators before retrieval, necessitating that meristic data at times be estimated using length-conversion equations (Table 1). These equations were used to estimate the length of 15 specimens where only HL could be measured. All length conversions were linear. The poorest estimator of SL was OW. The relationship between SL in millimeters and whole, wet body weight $(W)$ in grams was $W=0.00002$ $\mathrm{SL}^{3.0207}\left(R^{2}=0.979\right)$, which was a slightly better estimator of whole, wet biomass than otolith length in millimeters, $W=0.0651$ $\mathrm{OL}^{3.6902}\left(R^{2}=0.939\right)$.

In the otolith edge analysis, $91.6 \%$ of the otoliths still had an opaque edge in June. We considered these bands to be annuli (Lowerre-Barbieri et al. 1994). The onset of translucent rings began with the summer season, and they were found primarily in the summer and fall. For example, $97.8 \%$ of the fish caught during October had a transparent ring on the otolith's edge.

On average, yellowfin croaker were 101 $\mathrm{mm}$ SL during their first year and $170 \mathrm{~mm}$ SL during their second year. Growth began to slow in their third year (mean $=188 \mathrm{~mm}$ SL) as they became reproductive (Table 2). In the field we were able to visually determine 

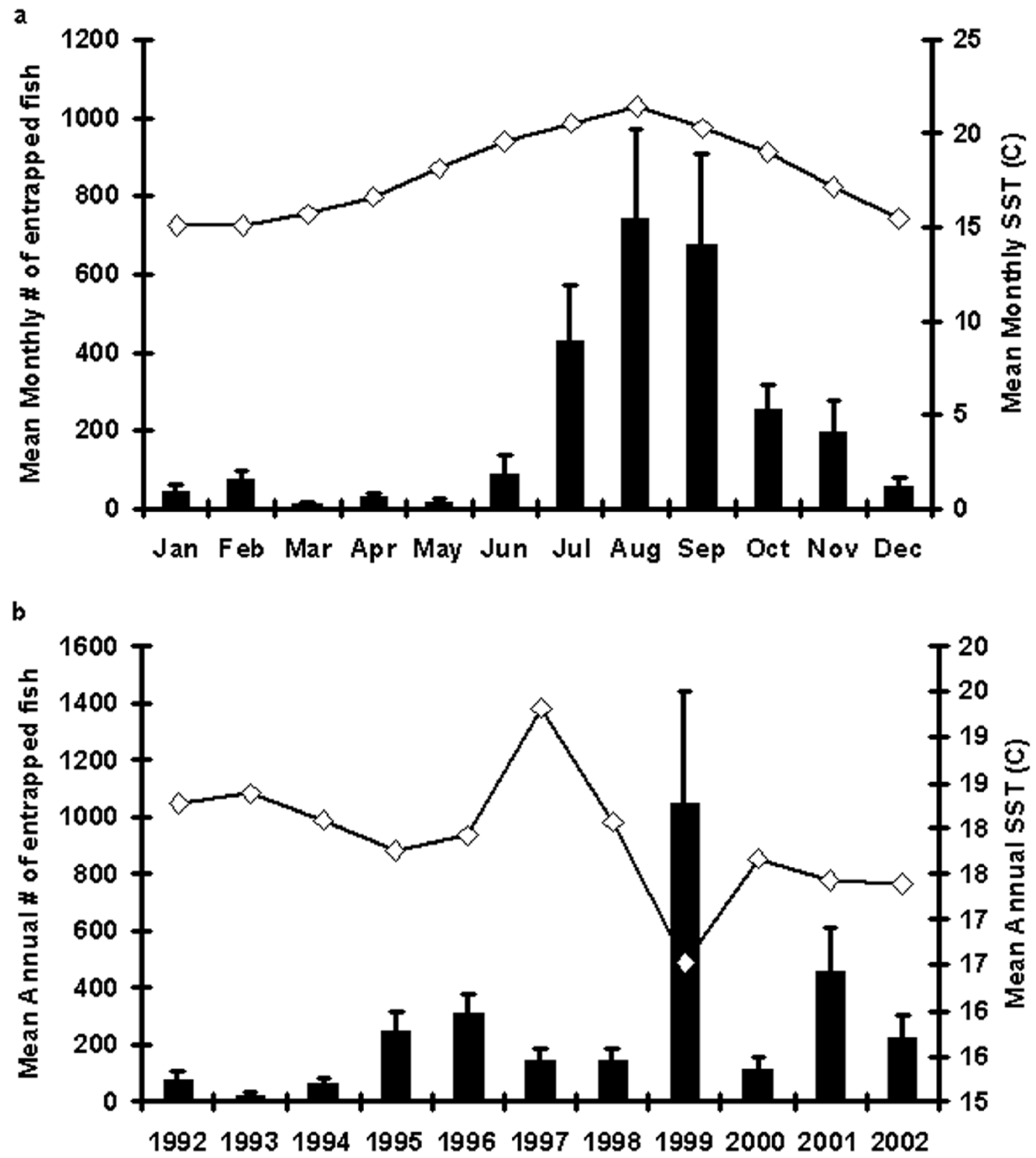

Figure 4. The monthly $(a)$ and annual $(b)$ mean number of entrapped yellowfin croaker per survey in the San Onofre Nuclear Generating Station (SONGS) and mean monthly and annual SST $\left({ }^{\circ} \mathrm{C}\right)$ measured at the Scripps Pier from 1992 to 2002. Monthly mean was significantly correlated with SST $(r=0.809, P=.001)$, and the annual mean was negatively correlated $(r=-0.751, P=.008)$.

the sex of $50 \%$ of the individuals by $150 \mathrm{~mm}$ SL and $100 \%$ by $200 \mathrm{~mm}$ SL. The overall male to female sex ratio $(51: 49)$ was not significantly different from a 50:50 ratio
$\left(X^{2}=0.7 ; P>.1\right)$, and males and females were found at all sizes. The largest sexed individual was a male of $395 \mathrm{~mm}$ SL, and the largest female was $365 \mathrm{~mm} \mathrm{SL}$. The oldest 
TABLE 2

Descriptive Statistics for Yellowfin Croaker by Age Class, Size (SL), and Maturity Determined in the Field for Fishes

\begin{tabular}{|c|c|c|c|c|c|c|c|c|c|c|c|c|}
\hline \multirow{2}{*}{$\begin{array}{l}\text { Age } \\
\text { Class }\end{array}$} & \multicolumn{4}{|c|}{$\begin{array}{l}\text { Females } \\
\text { SL (mm) }\end{array}$} & \multicolumn{4}{|c|}{$\begin{array}{c}\text { Males } \\
\text { SL (mm) }\end{array}$} & \multicolumn{4}{|c|}{$\begin{array}{l}\text { Immature } \\
\text { SL (mm) }\end{array}$} \\
\hline & $n$ & Mean & $\mathrm{SD}$ & Range & $n$ & Mean & $\mathrm{SD}$ & Range & $n$ & Mean & $\mathrm{SD}$ & Range \\
\hline 0 & 3 & 143 & 18 & $127-162$ & 5 & 145 & 11 & $127-154$ & 273 & 99 & 22 & $35-150$ \\
\hline 1 & 58 & 174 & 16 & $145-205$ & 66 & 169 & 16 & $146-211$ & 18 & 162 & 7 & $149-172$ \\
\hline 2 & 141 & 192 & 19 & $161-251$ & 174 & 184 & 17 & $157-240$ & 1 & 195 & & \\
\hline 3 & 62 & 234 & 23 & $175-271$ & 64 & 210 & 19 & $177-255$ & & & & \\
\hline 4 & 19 & 267 & 43 & $190-340$ & 12 & 220 & 21 & $185-257$ & & & & \\
\hline 5 & 40 & 268 & 34 & $203-338$ & 27 & 236 & 37 & $186-367$ & & & & \\
\hline 6 & 53 & 268 & 27 & $225-335$ & 37 & 252 & 24 & $200-296$ & & & & \\
\hline 7 & 18 & 281 & 24 & $239-327$ & 20 & 267 & 29 & $222-335$ & & & & \\
\hline 8 & 17 & 306 & 35 & $243-365$ & 14 & 271 & 28 & $232-325$ & & & & \\
\hline 9 & 10 & 292 & 22 & $260-325$ & 16 & 290 & 23 & $250-332$ & & & & \\
\hline 10 & 6 & 324 & 28 & $290-360$ & 11 & 299 & 16 & $272-324$ & & & & \\
\hline 11 & 2 & 312 & 40 & $284-340$ & 5 & 307 & 18 & $290-332$ & & & & \\
\hline 12 & 1 & 351 & & & & & & & & & & \\
\hline 13 & 2 & 356 & 1 & $355-357$ & & & & & & & & \\
\hline 15 & & & & & 2 & 354 & 58 & $313-395$ & & & & \\
\hline
\end{tabular}

Note: Fish whose sexual status or SL $(n=32)$ could not be measured or determined in the field were not included.

specimens were two 15 -yr-old males caught at Santa Barbara Island (13 June 2006; 395 mm SL) and Belmont Shores (28 February 1995; $313 \mathrm{~mm}$ SL). The largest yellowfin croaker (420 mm SL) was caught at Palos Verdes on 3 June 2003. This fish was $7 \mathrm{yr}$ old. The tail had been eaten, and we estimate that the TL would have been $510 \mathrm{~mm}$ based on conversion equations in Table 1 . This specimen also had the second largest otoliths $(\mathrm{OW}=8.00 \mathrm{~mm} ; \mathrm{OL}=13.50 \mathrm{~mm} ; \mathrm{OWt}=$ $0.4545 \mathrm{~g})$. The largest otoliths were from the 15-yr-old specimen caught at Santa Barbara Island $(\mathrm{OW}=6.72 \mathrm{~mm} ; \mathrm{OL}=13.96 \mathrm{~mm}$; $\mathrm{OWt}=0.4864 \mathrm{~g})$. The largest fish in the study was clearly on a different growth trajectory from the rest of the studied specimens (Figure 5), and many fish were above the $L_{\infty}$ values (Table 3 ).

The relationships of otolith length and width to age also fitted the von Bertalanffy growth model reasonably well (Table 3 ). All von Bertalanffy model values were significantly different between the sexes; females grew significantly faster and reached significantly larger size than males at age $\left(L_{\infty}: F=\right.$ $4.021 ; \mathrm{df}=1,1,465 ; P<.05 ; k: F=4.587$; $\mathrm{df}=1,1,465 ; P<.05 ; t: F=15.573 ; \mathrm{df}=$
$1,1,465 ; P<.01)$. Growth in length for both sexes began to slow with the onset of gonad development (Table 2, Figure 5). Of the three sampling periods in 2003 (June, August, and October) the peak in GSI for females and males was in August (Figure 6; $5.34 \% \pm 0.44 \%$ and $4.55 \% \pm 0.25 \%$, respectively). However in the following year the highest GSI values of the study were measured in June, with females $=5.65 \% \pm$ $0.40 \%$ and males $=5.51 \% \pm 0.23 \%$.

Overall annual total mortality $(A)$ and instantaneous coefficient of total mortality $(Z)$ calculated between the 2003 and 2004 sampling seasons were 0.4492 and 0.5964 , respectively. Using annual survivorship to calculate relative year class strength, we found that recruitment was greatest during the years 1993-1995, followed by 1997-1998 (Figure 7). Recruitment was not clearly correlated with SST $(r=0.535, P=.060)$ and has significantly declined since $1993(r=0.832$, $m=-412.8 \pm 86.9, P=.0008)$.

\section{DISCUSSION}

Yellowfin croaker exhibited growth and reproductive patterns typical of southern Cali- 


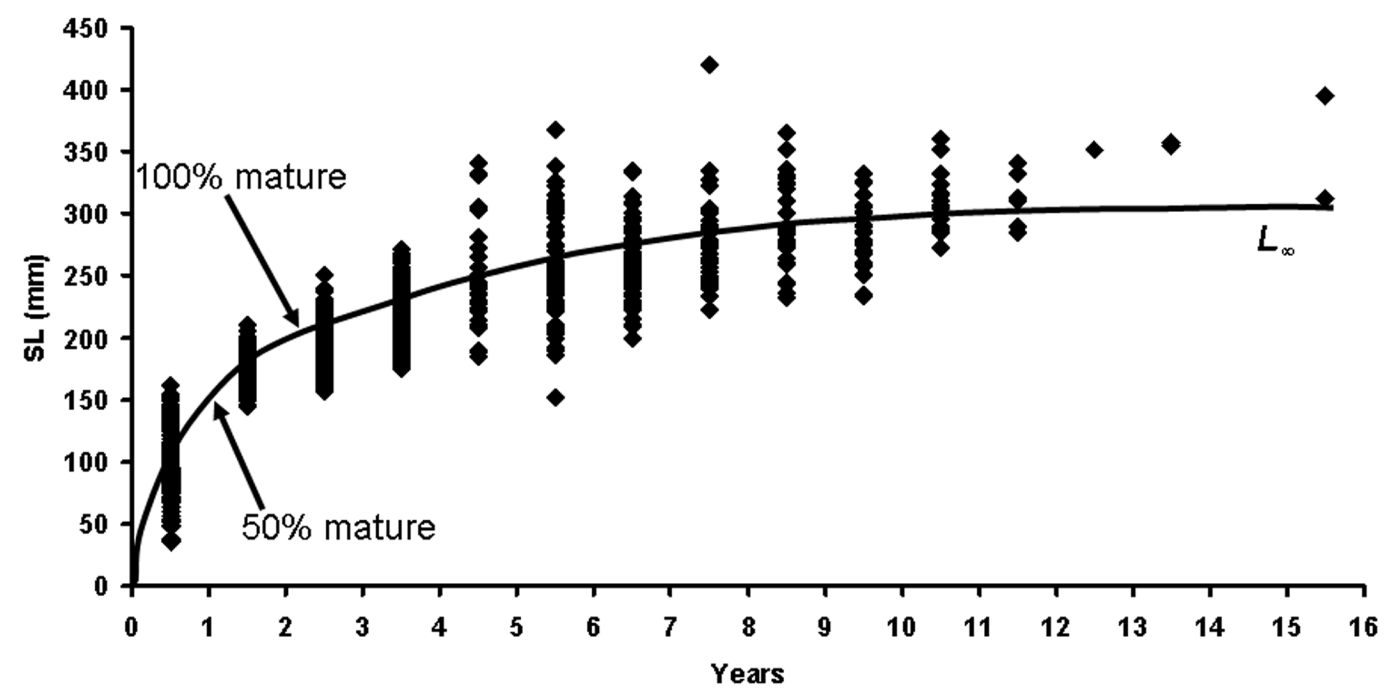

Figure 5. Size (SL) at age for 1,209 yellowfin croaker with a fitted von Bertalanffy growth curve was plotted. Size at $50 \%$ and $100 \%$ maturity was noted.

fornia nearshore fishes (e.g., Allen et al. 1995, Love et al. 1996). Growth was rapid through age three and slowed at the onset of reproductive maturity. These croakers grew fastest in the late summer and fall, beginning with the end of their summer reproductive period. This pattern was confirmed by rapid deposition in the otoliths. We report a maximum age of $15 \mathrm{yr}$. Notable variation in growth rates occurs between individuals. For example, the largest fish we studied $(420 \mathrm{~mm}$ SL; estimated $510 \mathrm{TL}$ ) was half the age of smaller, though similarly sized individuals. If it had not been partially eaten, this specimen would have weighed an estimated $1,679 \mathrm{~g}$, which is $79.9 \mathrm{~g}$ less than the California state record (O'Brien and Oliphant 2001). The longest reported yellowfin croaker $(556 \mathrm{~mm}$

TABLE 3

Output Parameters Obtained from a Statistical Fitting to the von Bertalanffy Model, Based upon SL, OW, and OL for All Fish, Females Plus Immature, and Males Plus Immature for Each of These Three Measurements

\begin{tabular}{lccr}
\hline \hline & \multicolumn{2}{c}{ Parameters Estimated } \\
\cline { 2 - 4 } Group & $L_{\infty}$ & $k$ & $t_{0}$ \\
\hline Standard Length estimation & & & -0.995 \\
$\quad$ All $(n=1,209)$ & 307.754 & 0.307 & -0.771 \\
All females and immature $(n=726)$ & 313.173 & 0.269 & -1.072 \\
All males and immature $(n=744)$ & 298.886 & 0.394 & -1.615 \\
Otolith Width estimation & & 0.527 & -0.837 \\
All $(n=890)$ & 5.993 & 0.474 & -1.176 \\
Females and immature $(n=433)$ & 6.000 & & -1.555 \\
Males and immature $(n=470)$ & 5.735 & 0.307 & -0.769 \\
Otolith Length estimation & & 0.418 & -1.228 \\
$\quad$ All $(n=890)$ & 11.205 & 0.350 & \\
Females and immature $(n=433)$ & 11.027 & 10.769 & \\
Males and immature $(n=470)$ & & & \\
\hline
\end{tabular}




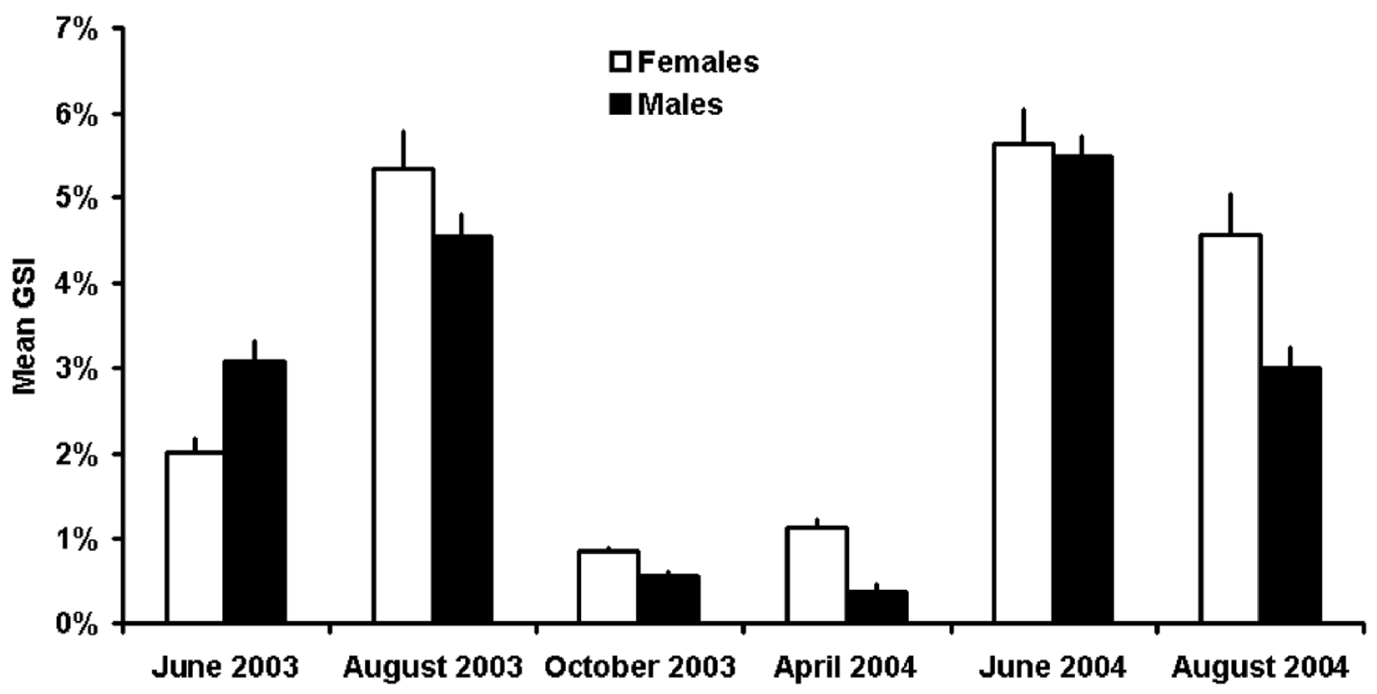

Figure 6. Mean gonadosomatic indices $( \pm 1 \mathrm{SE})$ for male and female yellowfin croaker on six occasions between June 2003 and August 2004.

TL), captured in the Point Loma Kelp Forest at the surface $\left(<2.4 \mathrm{~m} ; 32^{\circ} 43^{\prime} 41^{\prime \prime} \mathrm{N}, 117^{\circ}\right.$ $15^{\prime} 57^{\prime \prime}$ [W. M. Shane, pers. comm.; Love et al. 2005]), would have weighed $2,181 \mathrm{~g}$. With a large sample size, we found a number of individuals that were above and below the curve that was the best fit of the length data to the von Bertalanffy growth model. We cannot account for this variation.

Given that yellowfin croakers have a relatively high annual mortality rate $(A=0.45)$, individuals older than $15 \mathrm{yr}$ are likely to be

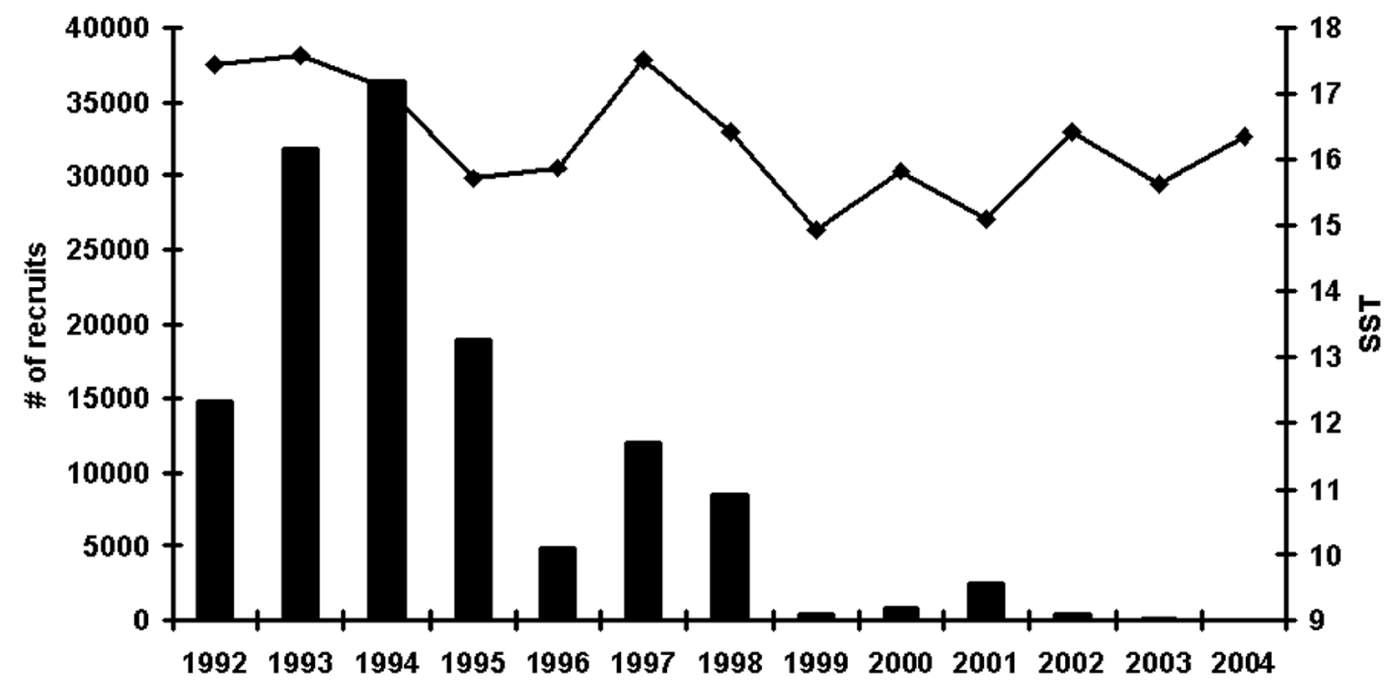

FIGURE 7. Estimated annual recruitment strength calculated from the 2003-2004 OREHP sampling season adjusted for annual survivorship $(1-A)$. 
extremely rare; we found only five individuals older than $11 \mathrm{yr}$ among the 1,209 fish in the study. As an evolutionary strategy, it appeared that rapid growth and early maturity were necessary to offset this relatively high mortality of both males and females. More than $50 \%$ of specimens could be visually sexed during their first year, and all showed reproductive development by the end of their second year of growth. This relatively high mortality, early maturity, and greater investment in reproduction for females seem consistent with our observations that females grew faster and larger than males.

Very little is known about the behavior of this species (Feder et al. 1974). They occur in all nearshore subtidal habitats and are generally wary of scuba divers. Single yellowfin croaker can be observed regularly on cobble and soft-bottom areas near reefs during the night at Santa Catalina Island. They appear to be nocturnal foragers (Hobson et al. 1981), and anecdotal observations indicate that they may make forays into reef habitats. In 1983-1984 trawl surveys, they were the 12th most abundant fish at $6.1 \mathrm{~m}$ depth but ranked 40th at $12.1 \mathrm{~m}$ depth (Love et al. 1986) and 23rd in abundance in beach seine catches from 1953 to 1956 (Carlisle et al. 1960). No observations have been made of their reproduction, but the gonadosomatic indices for males (up to $5.51 \%$ in June) were suggestive of a group-spawning species, with sperm competition being likely (Stockley et al. 1997). During their reproductive season, they become entrapped at SONGS, indicating that they are moving through that area (1 km offshore); it is possible that they are moving offshore to spawn. This hypothesis has been suggested for other southern California surf-zone croakers (Joseph 1962). An alternative hypothesis is that they may be spending the winter in deeper water (Skogsberg 1939). Both CPUE in the OREHP study and the number of entrapped fish at SONGS were correlated with SST. In warmer years and seasons, catch was greater near the surf zone, but during colder years the number of entrapped fish increased offshore, indicating that temperature may be one cue yellowfin croaker use for onshore/ offshore movement. It has been noted that there was annual variation in the onshore and offshore catch of this fish (Skogsberg 1939). The ratio of males to females collected was very close to unity $(51: 49)$, and males and females were present at all sizes; therefore yellowfin croaker are most likely gonochores. All the juveniles $(<100 \mathrm{~mm} \mathrm{SL})$ captured in this study were found on coastal sandy beaches, typically in or close to the surf zone throughout the bight.

Although yellowfin croaker have been described as one of the most abundant nearshore fishes in the southern California bight (Pondella and Allen 2000, Allen and Pondella 2006), their abundance as estimated by CPUE was highly variable in space and time. CPUE was significantly lower at Santa Barbara and Ventura and intermediate at Malibu. The northern edge of the southern California bight is classically defined as Point Conception. The San Diegan Province community, to which yellowfin croaker belong, makes a transition to the Oregonian Province along that stretch of coastline, with Santa Monica Bay being the last mainland warm refuge in the bight (Pondella et al. 2005, Horn et al. 2006). This transition point, rather than Point Conception, appeared to provide the northern limit of and significant CPUE of yellowfin croaker.

In the OREHP time series CPUE increased to a maximum in June 1997 and then decreased with the exception of 2002 through most years with a low in the April 2004 sampling period. The early increase in CPUE appeared to be related to the strong year classes of 1993-1995 (Figure 7). However, as recruitment significantly declined throughout the remainder of the study, CPUE also declined. We do not know the reason for this decline in recruitment, but we note a correlation with the onset of dramatic red tides in the late 1990s (Gregorio and Pieper 2000, Schnetzer et al. 2007). These tides were present during the times and in the areas where yellowfin croaker recruit and may have been a factor in the declines. With such dramatic variations in indicators of adult stock, juve- 
nile recruitment, spatial distribution, and a reproductive strategy that may employ group spawning, we recommend a cautious management approach for this fishery species.

\section{ACKNOWLEDGMENTS}

This study would not have been possible without the funding of the California Department of Fish and Game's Ocean Resource Enhancement Hatchery Program from which we would like to thank Larry Allen and Brent Haggin; Chevron Products Company from which we would like to thank Wayne Ishimoto; and the California Energy Commission's WISER program from which we would like to thank Lara Ferry-Graham. We also could not have completed this project without the assistance of the students from the Vantuna Research Group at Occidental College and the Nearshore Marine Fish Program at California State University Northridge. Kevin Herbinson kindly provided the fish entrapment data from SONGS.

\section{Literature Cited}

Allen, G. R., and D. R. Robertson. 1994. Fishes of the tropical eastern Pacific. University of Hawai'i Press, Honolulu.

Allen, L. G., T. E. Hovey, M. S. Love, and J. T. W. Smith. 1995. The life history of the spotted sand bass (Paralabrax maculatofasciatus) within the southern California bight. Calif. Coop. Oceanic Fish. Invest. Rep. 36:193-203.

Allen, L. G., and D. J. Pondella II. 2006. Surf zone, coastal pelagic zone, and harbors. Pages 149-166 in L. G. Allen, D. J. Pondella II, and M. Horn, eds. The ecology of marine fishes: California and adjacent waters. University of California Press, Los Angeles.

Barbieri, L. R., M. E. Chittenden Jr., and S. K. Lowerre-Barbieri. 1994. Maturity, spawning, and ovarian cycle of Atlantic Croaker, Micropogonias undulatus, in the Chesapeake Bay and adjacent coastal waters. Fish. Bull. 92:671-685.

Carlisle, J. G., Jr., J. W. Schott, and N. J.
Abramson. 1960. The barred surfperch (Amphistichus argenteus Agassiz) in southern California. Calif. Dep. Fish Game Fish Bull. 109.

Craig, M. T., D. J. Pondella II, and J. C. Hafner. 1999. Analysis of age and growth in two eastern Pacific groupers (Serranidae: Epinephelinae). Bull. Mar. Sci. 65:807814.

De La Cruz-Agüero, J., F. Galvan-Magaña, L. A. Abitia-Cardenas, J. RodriguezRomero, and F. J. Gutierrez-Sanchez. 1994. Systematic list of marine fishes from Bahia Magdalena, Baja California Sur (Mexico). Cienc. Mar. 20:17-31.

Eschmeyer, W. N., and E. S. Herald. 1983. A field guide to Pacific coast fishes: North America. Houghton Mifflin Co., Boston, Massachusetts.

Feder, H. M., C. H. Turner, and C. Limbaugh. 1974. Observations on fishes associated with kelp beds in southern California. Calif. Dep. Fish Game Fish Bull. 160.

Gobalet, K. W. 2000. Has Point Conception been a marine zoogeographic boundary throughout the Holocene? Evidence from the archaeological record. Bull. South. Calif. Acad. Sci. 99:32-44.

Gregorio, D., and R. Pieper. 2000. Investigations of red tides along the southern California coast. Bull. South. Calif. Acad. Sci. 99:147-160.

Hobson, E. S., W. N. McFarland, and J. R. Chess. 1981. Crepuscular and nocturnal activities of Californian nearshore fishes, with consideration of their scotopic visual pigments and the photic environment. Fish. Bull. 79:1-30.

Horn, M. H., and L. G. Allen. 1985. Fish community ecology in southern California bays and estuaries. Pages 169-190 in A. Yanez-Arancibia, ed. Fish community ecology in estuaries and coastal lagoons: Towards an ecosystem integration. $\mathrm{Na}$ tional Autonomous University of Mexico Press, Mexico.

Horn, M. H., L. G. Allen, and R. N. Lea. 2006. Biogeography. Pages 3-25 in L. G. Allen, D. J. Pondella II, and M. Horn, 
eds. The ecology of marine fishes: California and adjacent waters. University of California Press, Los Angeles.

Joseph, D. C. 1962. Growth characteristics of two southern California surffishes, the California corbina and spotfin croaker, family Sciaenidae. Calif. Dep. Fish Game Fish Bull. 119.

Legendre, P., and L. Legendre. 1998. Numerical ecology, 2nd English ed. Elsevier Science B. V., Amsterdam, the Netherlands.

Love, M. S., A. Brooks, D. Busatto, J. S. Stephens Jr., and P. A. Gregory. 1996. Aspects of the life histories of the kelp bass, Paralabrax clatbratus, and barred sand bass, Paralabrax nebulifer, from the southern California bight. Fish. Bull. 94:472-481.

Love, M. S., G. E. McGowen, W. Westphal, R. J. Lavenberg, and K. Martin. 1984. Aspects of the life history and fishery of the white croaker, Genyonemus lineatus (Sciaenidae), off California. Fish. Bull. 82:179198.

Love, M. S., G. W. Mecklenburg, T. A. Mecklenburg, and L. K. Thorsteinson. 2005. Resource inventory of marine and estuarine fishes of the West Coast and Alaska: A checklist of North Pacific and Arctic Ocean species from Baja California to the Alaska-Yukon border. U.S. Department of the Interior, U.S. Geological Survey, Biological Resources Division, Seattle, Washington, OCS study MMS 2005-030 and USGS/NBII 2005-001.

Love, M. S., M. Sandhu, J. Stein, K. T. Herbinson, R. H. Moore, M. Mullin, and J. S. Stephens Jr. 1989. Analysis of fish diversion efficiency and survivorship in the fish return system at San Onofre Nuclear Generating Station. NOAA Tech. Rep. NMFS 76.

Love, M. S., J. S. Stephens Jr., P. Morris, M. M. Singer, M. Sandhu, and T. C. Sciarrotta. 1986. Inshore soft substrate fishes in the southern California bight: An overview. Calif. Coop. Oceanic Fish. Invest. Rep. 27:84-106.

Lowerre-Barbieri, S. K., M. E. Chittenden Jr., and C. M. Jones. 1994. A comparison of a validated otolith method to age weakfish, Cynoscion regalis, with the traditional scale method. Fish. Bull. 82:555-568.

Miller, D. J., and R. N. Lea. 1972. Guide to the coastal marine fishes of California. Calif. Dep. Fish Game Fish Bull. 157.

Musick, J. A., M. M. Harbin, S. A. Berkeley, G. H. Burgess, A. M. Eklund, L. Findley, R. G. Gilmore, J. T. Golden, D. S. Ha, G. R. Huntsman, J. C. McGovern, S. J. Parker, S. G. Poss, E. Sala, T. W. Schmidt, G. R. Sedberry, H. Weeks, and S. G. Wright. 2000. Marine, estuarine, and diadromous fish stocks at risk of extinction in North America. Fisheries (Bethesda) 25 (11): 6-30.

Nelson, J. S. 2006. Fishes of the world, 4th ed. John Wiley \& Sons, Hoboken, New Jersey.

O'Brien, J. W., and M. S. Oliphant. 2001. Yellowfin croaker. Pages 232-233 in W. S. Leet, C. M. Dewees, R. Klingbeil, and E. J. Larson, eds. California's living marine resources: A status report. California Department of Fish and Game, Sacramento.

Pondella, D. J., II, and L. G. Allen. 2000. The nearshore fish assemblage of Santa Catalina Island. Pages 394-400 in D. R. Browne, K. L. Mitchell, and H. W. Chaney, eds. The Proceedings of the 5th California Islands Symposium. Santa Barbara Museum of Natural History, Santa Barbara, California.

Pondella, D. J., II, B. E. Gintert, J. R. Cobb, and L. G. Allen. 2005. Biogeography of the nearshore rocky-reef fishes at the southern and Baja California islands. J. Biogeogr. 32:187-201.

Ratkowsky, D. A. 1983. Nonlinear regression modeling. Marcel Dekker, New York.

Ricker, W. E. 1975. Computation and interpretation of biological statistics of fish populations. Fish. Res. Board Can. Bull. 191:1-382.

Sala, E., E. Ballesteros, and R. M. Starr. 2001. Rapid decline of Nassau grouper spawning aggregations in Belize: Fishery management and conservation needs. Fisheries (Bethesda) 26 (10): 23-30.

Schnetzer, A., P. E. Miller, R. A. Schaffner, 
B. A. Stauffer, B. H. Jones, S. B. Weisberg, P. M. DiGiacomo, W. M. Berelson, and D. A. Caron. 2007. Blooms of Pseudonitzschia and domoic acid in the San Pedro Channel and Los Angeles harbor areas of the southern California bight, 2003-2004. Harmful Algae 6:372-387.

Skogsberg, T. 1939. The fishes of the family Sciaenidae (croakers) of California. Calif. Dep. Fish Game Fish Bull. 54.

Sokal, R. R., and F. J. Rohlf. 2000. Biometry: The principles and practice of statistics in biological research, 3rd ed. W. H. Freeman and Company, San Francisco.
Stockley, P., M. J. G. Gage, G. A. Parker, and A. P. Moller. 1997. Sperm competition in fishes: The evolution of testis size and ejaculate characteristics. Am. Nat. 149:933-954.

Studenmund, A. H. 2001. Using econometrics: A practical guide, 4th ed. Addison Wesley Longman, Reading, Massachusetts.

Vojkovich, M., and R. J. Reed. 1983. White seabass, Atractoscion nobilis, in CaliforniaMexican waters: Status of the fishery. Calif. Coop. Oceanic Fish. Invest. Rep. 24:79-83. 